\title{
The Portrait of the Students' Ability to Read and Write Al-Quran at UIN Ar-Raniry Aceh
}

\author{
$1^{\text {st }}$ Dwi Martiningsih ${ }^{1}, 2^{\text {nd }}$ Arif Zamhari ${ }^{2}$ \\ \{dweemart@kemenag.go.id ${ }^{1}$, arif.zamhari@uinjkt.ac.id² ${ }^{2}$ \\ Lajnah Pentashihan Mushaf Al-Qur'an (LPMQ) Research and Development Agency and Training of the \\ Ministry of Religious Affairs of the Republic of Indonesia ${ }^{1}$, UIN Syarif Hidayatullah Jakarta ${ }^{2}$.
}

\begin{abstract}
In the national education system, the ability to read and write the Qur'an has become a competency that students in Islamic universities must be fulfilled. Based on the results of LPMQ research conducted by the Ministry of Religious Affairs of the Republic of Indonesia's Research and Development Agency and Training in 2019 on the Al-Qur'an Reading and Writing (BTQ) Ability Index at 11 State Islamic Universities (PTIN) in Indonesia, UIN Ar-Raniry Aceh came in the last second from the bottom. This paper seeks to explain why UIN Ar-Raniry Aceh students have low ability in reading and writing the Qur'an. This article uses case study method. Questionnaires, interviews, Quranic reading and writing tests, and documentation were used to collect data. The findings of the data analysis reveal that both internal and external variables contributed to the poor BTQ ability of UIN Ar-Raniry Aceh students. Internal factors focus on students' poor motivation to learn the Qur'an, which is exacerbated by external factors, such as a familial setting that discourages the development of habits to engage with the Qur'an in everyday life.
\end{abstract}

Keywords: Portrait, Al-Quran Reading and Writing Ability, UIN Ar-Raniry Aceh.

\section{Introduction}

The Qur'an is a Muslim holy book that is considered to be a divine revelation from Allah SWT that was given to Prophet Muhammad SAW and passed down to his people in a way of mutawatir[1]. Reading the Qur'an is a kind of worship that is rewarded. As stated in Q.S AlAlaq 96/1-5, learning the Qur'an is God's mandate. There is a command in the verse to read the Qur'an frequently so that it might permeate into one's spirit.

Al-Qur'an brings benefits to its readers. By citing and interpreting Q.S. Yunus/10: 57, Ahmad Musthofa Al Maraghi claims that the Qur'an may enhance the human spirit in a variety of ways: as a good advisor, a remedy for all heart illnesses, a guide to the path of truth and belief, and a mercy for those who believe[2].

Although reading Al-Qur'an has been taught to Muslims in Indonesia since their early informal education, their ability to read and write Al-Qur'an needs more attention. In fact, many Muslim students have not been able to read and write Al-Qur'an. This fact is discovered on Muslim students at UIN Sunan Gunung Djati Bandung's Faculty of Science and Technology, who have poor skill of reading and writing Qur'an. To deal with this problem, the university provide special methods to improve their skills using the Tamam method which can help UIN Sunan Gunung Djati students to enhance their ability to read and write the Qur'an[3]. 
Moreover, Muslim students' interest towards reading Al-Qur'an is low in the primary teacher education study program at UNISBA Blitar. They are unable to read Al-Qur'an or halting in reading Al-Qur'an. Some students prefer to read other readings than Al-Qur'an such as novel, magazine, book, and others. Another factor of the decrease of reading interest of AlQur'an is the advancement of technology. They prefer using gadget for unimportant things, for example, spending spare time by accessing social media. Besides, lack of Al-Qur'an teachers is the main factor that influences the decrease of interest towards reading Al-Qur'an. Despite this fact, they are willingly to improve their ability in reading Al-Qur'an even though they had to learn from zero level[4].

Likewise, the profile of abilities in reading and writing al-Quran by the students of Islamic education program at Universitas Islam Negeri Imam Bonjol Padang in general has not been satisfied yet. However, their low rate of reading and writing abilities has been successfully dealt with the University representative by conducting a program Tahsin alQuran[5].

A preliminary research result shows that most of the students of a university in Sumedang Regency, West Java, Indonesia, are not able to read Quran fluently and correctly. To address this issue, a reflective-critical action research is conducted collaboratively by implementing TAHQIQ approach of Quran learning to students of a university in Sumedang Regency. The result shows that students' improvement skill rate reaches $90.2 \%$. Moreover, the success rate, which is seen from the students' improvement from non-fluent to fluent level, reaches $65.08 \%$. As far as these figures are concerned, this research results can be used as one of the alternatives of eradicating the ignorance of reading or illiteracy of the Quran at university level[6].

Students from Islamic education study program, Faculty of Education, and Teacher Training at UIN Sunan Ampel likewise has low BTQ (Read and Write al-Qur'an) abilities in 2015. According to Iffatunnuha's findings, educational background, family, friends, school, and society are all variables that influence PAI FTKP UINSA students' ability to read and write the Qur'an (BTQ)[7].

A similar problem was also discovered among IAIN Curup students. In 2017, Rafia Arcanita performed a study on the impact of Ma'had Al-Jamiah in helping IAIN Curup students overcome their inability to read the Quran. The study's findings revealed the significance of the Ma'had al-Jami'ah program in promoting student competency in the subject of the Qur'an through the implementation of a semi-classical Islamic boarding school curriculum[8].

The aforementioned phenomena have prompted Lajnah Pentashihan Mushaf Al-Qur'an (LPMQ) to conduct research on the Al-Qur'an Reading and Writing Ability Index (BTQ) at PTIN (State Islamic Higher Education), with 11 leading PTINs in Indonesia as the subjects of the study: UIN Syarif Hidayatullah Jakarta, UIN Sunan Kalijaga Yogyakarta, UIN Sunan Gunung Djati Bandung, UIN Sunan Ampel Surabaya, UIN Malang, UIN Ar-Raniry Aceh, UIN Sumatera Utara, UIN Palembang, UIN Riau, UIN Mataram dan UIN Ternate. According to the findings of Jaeni's et al study, UIN students' Al-Qur'an reading and writing indexes were moderate nationally, but poor or extremely low in a number of UINs. Among Indonesia's major Islamic universities, UIN Ar-Raniry Aceh came in second from the bottom in terms of students' Qur'an reading and writing abilities[9]. This study will go into further detail regarding this, as well as the probable causes. 


\section{Methodology}

This study relies on primary data, which was gathered through the Al-Quran reading and writing ability test, questionnaires, and interviews. This study will focus on the students' capacity to read and write the Qur'an, as well as the elements that impact this ability.

The population in the study were students at UIN Ar-Raniri Aceh, with samples obtained from $50 \%$ of General Faculty students and $50 \%$ of Religious Faculty students. The number of students that responded was 50 in semesters 5 and 6, with 25 males and 25 females. Purposive random selection was used to compare Qur'an reading and writing skills among students from UIN Ar-Raniry Aceh's General Study Program and Religious Study Program.

\subsection{Various Methods for Learning the Qur'an}

The capacity to read and write the Qur'an refers to a person's competence and ability in doing so. There are several indicators for measuring the ability to read and write the Qur'an, according to Madyan, including understanding how to pronounce the hijaiyah letters and their punctuation marks, compiling words with hijaiyah letters both separately and in succession, and applying the tajwid rules in reading the Qur'an[10].

The objective of tajwid, according to Chaer, is to maintain the reading of the Qur'an from reading mistakes. Although learning the science of recitation is fard kifayah, but reading the Qur'an according to the norms of the science of tajwid is fardhu 'ain[11].

According to Siddiq, there are four ways to learn the Qur'an: Baghdadi, Iqra, Qiraati, and Tilawati. Meanwhile, according to Fauzan, Baghdadi, Iqra, Qiraati, Al-Barqi, and Tilawati are five different Al-Quran study techniques[12]. The Baghdadiyah technique, also known as the spelling method, was developed in Baghdad during the time of the Abbasid Caliphs. In general, the Baghdadiyah rule needs 17 stages with 30 hijaiyah letters shown in full in each phase. Meanwhile, Iqra method was compiled by As'ad Humam from Kotagede, Yogyakarta, which was further developed by AMM (Youth Generation of Mosques and Mushola) Yogyakarta by establishing an Al-Qur'an Kindergarten and TPQ (Al-Qur'an Education School)[13].

The Iqra method is divided into six volumes, each with a different color cover to pique students' interest. There is no parsing or spelling out of the content for volume 1 of the Iqra technique with "direct reading." Students are quickly exposed to linking letters after learning the hijaiyah letters, and they are conditioned to know the passages of the Qur'an, even if they are fragments of verses. A recitation guide (tajwid) is also included with the Iqra technique[13].

The Qiraati method was invented by KH Dachlan Salim Zarkasyi from Semarang. Since the 1970s, the Qiraati technique has been in use. KH Dachlan released 6 volumes of literature for TPQ students aged 4-6 years on July 1, 1986. The aims of the Qiraati technique were broadened during its development. There are now 13 Qiraati for children aged 4-6 years, children aged 6-12 years, and college students[14].

Muhadjir Sulthon, a lecturer at IAIN Sunan Ampel Surabaya's Faculty of Letters, created the Barqi technique in 1965. Originally, al-Barqi was designed for students at At-Tarbiyah Islamic Elementary School Surabaya. Students who learn to read the Quran using the al-Barqi technique do so more rapidly. Muhadjir published How to Quickly Learn Reading Al-Qur'an al-Barqi in 1978, which detailed the al-Barqi technique[13].

A team led by Drs. H. Hasan Sadzili, H. Ali Muaffa, and others invented the tilawati method in 2002. The Nurul Falah Virtual Islamic Boarding School in Surabaya later refined 
this approach.[14] The tilawati method reads the Qur'an using a variety of recitation songs to keep it interesting and to stress students' ability to read the Qur'an in tartil[13].

\subsection{Factors Affecting the Ability to Read and Write the Qur'an}

In general, there are two factors that affect the ability to read and write the Qur'an: internal factors (physiological and psychological) and external factors (instrumental factors, family, and society)[14].

Physiological factors are linked to a person's bodily state (physical freshness) as well as the condition of the five senses, particularly the eyes and ears as senses of sight and hearing. While psychological factors consist of several things: intelligence, talents and interests. Intelligence is related to the capacity to capture the information of a lesson quickly, the endurance of paying attention, the encouragement of curiosity and initiative, the speed with which a concept is grasped, the ability to abstract, and a broad interest in the topic being taught[15]. Talent (aptitude) is a person's intrinsic capacity to attain future achievement. It is innate from birth[16]. Instrumental factors are external factors that affect learning including: teachers, curriculum, infrastructure and environment. In addition to instrumental factors, external learning factors are also influenced by family and community support[17].

\subsection{Indicators of Ability to Read and Write Al-Qur'an}

Someone is compelled to read the Qur'an due to a strong desire or motivation. According to Hasbi Siddiq, there are three indications that may be used to assess tadarus (reading) alQur'an motivation: first, attempts to comprehend the Qur'an's content; second, the frequency or intensity in doing tadarus Al-Qur'an; third, the tadarus Al-Qur'an practice[12].

According to Madyan, there are various indications for evaluating a person's Qur'an reading and writing skill, including tartil in reading the Qur'an, recitation accuracy (tajwid), and fluency in reading the Qur'an[10]. Tartil in Qur'an reading is reading the Qur'an quietly with tadabbur, at a standard pace level, so that the reader can satisfy each reading law and the qualities of the letters described to the maximum extent possible. This is aligned with God's word (Surah Al-Muzammil/73:04). The meaning of this verse is to read the Qur'an slowly and understand the meaning of the letter (in a tartil way) (Surah al-Muzammil: 04).

\section{Result and Discussion}

There are five levels of ability to read the Qur'an. The first (lowest) level is the capacity to pronounce hijaiyah letters with a vowel in line with the makhraj, either in the single form or in the arrangement of letters. The second (low) level includes the fundamental capacity to read mad asli and idzhar halqiyah readings. The third (middle) level is the ability to read ghunnah, qalqalah, mad arid lis-sukun, mad iwad, mad wajib, and mad jaiz. The fourth (middle) level covers the ability to read idgham bighunnah, idgham bilaghunnah, iqlab, ikhfa, mad lazim mutsaqal kilmi, and mad layin. The fifth (highest) level is the ability to read gharib and fawatihus-suwar readings[9].

The capacity to write the Qur'an is likewise divided into five levels. The capacity to write a single hijaiyah letter is the initial (and lowest) level. The capacity to duplicate some hijaiyah letters is the second (low) level. The capacity to link hijaiyah letters is the third level (medium). The capacity to replicate Arabic words complete with the syakal is the fourth level 
(high). The capacity to reproduce one of the short suras in the Qur'an completely is the fifth (highest) level.

Table 1. Reading and Writing Ability of the Students of UIN Ar-Raniry Aceh in General

\begin{tabular}{|l|l|l|l|l|}
\hline Level & \multicolumn{4}{|c|}{ The Ability of the Students of UIN Ar-Raniry Aceh } \\
\hline & Reading al-Qur'an & Percentage & Writing Al-Qur'an & Percentage \\
\hline 0 & - & $0 \%$ & 2 students & $4 \%$ \\
\hline 1 & 12 students & $24 \%$ & 20 students & $40 \%$ \\
\hline 2 & 8 students & $16 \%$ & 4 students & $8 \%$ \\
\hline 3 & 9 students & $18 \%$ & 11 students & $22 \%$ \\
\hline 4 & 19 students & $38 \%$ & 7 students & $14 \%$ \\
\hline 5 & 2 students & $4 \%$ & 6 students & $12 \%$ \\
\hline
\end{tabular}

According to the data, UIN Ar-Raniry Aceh students had the high capacity to read the Qur'an at level 4, with 19 out of 50 respondents (38\%) who are able to do so. This indicates that UIN Aceh students have a good level of aptitude to read the Qur'an. However, the capacity to read and write the Qur'an at UIN Ar-Raniry Aceh is the second from the bottom of the 11 UINs in Indonesia that became the research area by LPMQ. The poor level of ability to write the Qur'an among UIN Ar-Raniry Aceh students is the reason of this case. According to the research, UIN Ar-Raniry Aceh students are the most at level 1 (low) in writing the Qur'an, with 20 students (40\%). In other words, the majority of UIN Aceh students' ability to write the Qur'an falls into the lowest level.

Table 2. UIN Ar-Raniry Aceh Students' BTQ Ability Based on Gender

\begin{tabular}{|c|c|c|c|c|}
\hline \multirow[b]{3}{*}{ Level } & \multicolumn{4}{|c|}{ The Ability of UIN Ar-Raniry Aceh Students } \\
\hline & \multicolumn{2}{|c|}{ To Read Al-Qur'an } & \multicolumn{2}{|c|}{ To Write Al-Qur'an } \\
\hline & Male & Female & Male & Female \\
\hline 0 & 0 student $(0 \%)$ & 0 student $(0 \%)$ & 2 students $(4 \%)$ & 0 student $(0 \%)$ \\
\hline 1 & 9 students (18\%) & 3 students $(6 \%)$ & 13 students $(26 \%)$ & 7 students $(14 \%)$ \\
\hline 2 & 4 students $(8 \%)$ & 4 students $(8 \%)$ & 0 student $(0 \%)$ & 4 students $(8 \%)$ \\
\hline 3 & 3 students $(6 \%)$ & 6 students $(12 \%)$ & 6 students $(12 \%)$ & 5 students $(10 \%)$ \\
\hline 4 & 7 students $(14 \%)$ & 12 students $(24 \%)$ & 0 student $(0 \%)$ & 7 students $(14 \%)$ \\
\hline 5 & 2 students $(4 \%)$ & 0 student $(0 \%)$ & 4 student $(8 \%)$ & 2 students $(4 \%)$ \\
\hline
\end{tabular}

The ability to read the Qur'an of UIN Ar-Raniry students based on gender shows that male students' ability to read the Qur'an is lower than female students. The majority of male students have reading ability at level 1 (lowest category), with 9 students, and level 4 (highest category), with 7 students. Unlike the male students, the majority of female students can read 
at level 4 (high category), with 12 students, followed by level 3 (medium category) with 6 people, and there are no female students who cannot read the Al-Qur'an.

The ability to write the Qur'an of UIN Ar-Raniry students based on gender shows that male students' writing skill is lower than female students. The majority of male students have writing abilities at level 1 (poor category), with 13 students, and level 3 (medium category), with 6 students. In contrast, the majority of female students have writing abilities at level 1 (low category) and 4 (high category), each level consists of seven students, and no female students are unable to write the Qur'an. This is different from male students that there are 2 students who are at level 0 (unable to write the Qur'an or do not a good understanding of the hijaiyah letters).

Table 3. UIN Ar-Raniry Aceh Students' BTQ Ability Based on Study Program

\begin{tabular}{|c|c|c|c|c|}
\hline \multirow[b]{3}{*}{ Level } & \multicolumn{4}{|c|}{ The Ability of UIN Ar-Raniry Aceh Students } \\
\hline & \multicolumn{2}{|c|}{ To Read Al-Qur'an } & \multicolumn{2}{|c|}{ To Write Al-Qur'an } \\
\hline & $\begin{array}{c}\text { General Study } \\
\text { Program }\end{array}$ & $\begin{array}{c}\text { Religious Study } \\
\text { Program }\end{array}$ & $\begin{array}{l}\text { General Study } \\
\text { Program }\end{array}$ & $\begin{array}{c}\text { Religious Study } \\
\text { Program }\end{array}$ \\
\hline 0 & 0 student $(0 \%)$ & 0 student $(0 \%)$ & 2 students $(4 \%)$ & 0 student $(0 \%)$ \\
\hline 1 & 9 students $(18 \%)$ & 3 students $(6 \%)$ & 13 students $(26 \%)$ & 7 students $(14 \%)$ \\
\hline 2 & 6 students $(12 \%)$ & 2 students $(4 \%)$ & 3 students $(6 \%)$ & 1 student $(2 \%)$ \\
\hline 3 & 5 students $(10 \%)$ & 4 students $(8 \%)$ & 4 students $(8 \%)$ & 7 students $(14 \%)$ \\
\hline 4 & 5 students $(10 \%)$ & 14 students $(28 \%)$ & 3 students $(6 \%)$ & 4 students $(8 \%)$ \\
\hline 5 & 0 student $(0 \%)$ & 2 orang $(4 \%)$ & 0 student $(0 \%)$ & 6 students $(12 \%)$ \\
\hline
\end{tabular}

If we look at it in terms of study program (general or religious), we can see that students in the Religious Study Program have a better capacity to read the Qur'an than students in the general study program. The majority of students in the Religious Studies Study Program (14 individuals) can read the Quran at level 4 (high), but the ability to read the Quran in the General Study Program (9 students) is primarily at level 1 (low).

Based on the study program, the students' ability to write the Qur'an at UIN Ar-Raniry Aceh General Study Program was discovered to be primarily at level 1 (low), with 13 students, and level 3 (medium), with 3 students. In terms of Qur'an writing, there are no students in general study programs that achieve level 5. Students in the Religion Study Program, on the other hand, have a writing skill that ranges from level 1 (7 students) to level 3 (7 students). Level 0 students do not exist in the Religion Study Program (not able to write). Unlike students in the Religion Study Program, there are 2 students in the General Study Program who are at level 0 (unable to write the Qur'an).

According to the researchers' questionnaire, there are numerous reasons that contribute to UIN Ar-Raniry Aceh students' poor reading and writing skills. First, when asked how long they had studied the Qur'an, the majority of the respondents said they had studied for more than 6 years, with 36 individuals saying they had studied for more than 6 years (more than $50 \%$ ). As a result, the majority of the students have a long time of learning the Qur'an. However, when it comes to daily Qur'an reading time, the majority of UIN Aceh students, who are 25 individuals (50\%), read the Qur'an in less than 30 minutes, while 18 students read the Qur'an for one to two hours every day. The lack of engagement with the Qur'an is the 
source of the students' poor ability to read and write the Al-Qur'an at UIN Ar-Raniry Aceh. Reading the Qur'an is a relatively rare occurrence, with just $1 \%$ of people doing so. Only $1 \%$ of families favor the creation of an atmosphere where the Qur'an may be read regularly (very low). These two variables demonstrate UIN Ar-Raniry Aceh students' limited ability to read and write the Qur'an.

In terms of teachers, respondents said that the majority of their Quranic teachers $(58 \%)$ memorized the Qur'an, while 21 teachers (42\%) did not. The low of UIN Ar-Raniry students' ability to read and write al-Quran is also attributable to the fact that the majority of their attendance to the Quran instructor did not reach the completion of $30 \mathrm{juz}$ (58\%), with only 21 students $(42 \%)$ reading up to $30 \mathrm{juz}$. UIN Ar-Raniry has tried a number of initiatives in terms of campus policy, including hosting a Qur'an reading exam for students who have just enrolled and been considered to have passed UIN Ar-Raniry. In addition, all new students must take the tahsin course. On the other side, the campus requires students to be able to read and write the Qur'an in order to graduate or receive a diploma.

UIN Ar Raniry Aceh has facilitated campus mosques, al-Qur'an manuscripts, CDs or murotals of the Quran to hafidz and hafidzhoh teachers at Ma'had Ali to provide a suitable atmosphere for UIN Aceh students to learn to read and write the Qur'an. To establish a conducive environment for learning the Qur'an, UIN Aceh students are required to remain in a dormitory for a minimum of 6 months at Ma'had Al Jami'ah for new students.

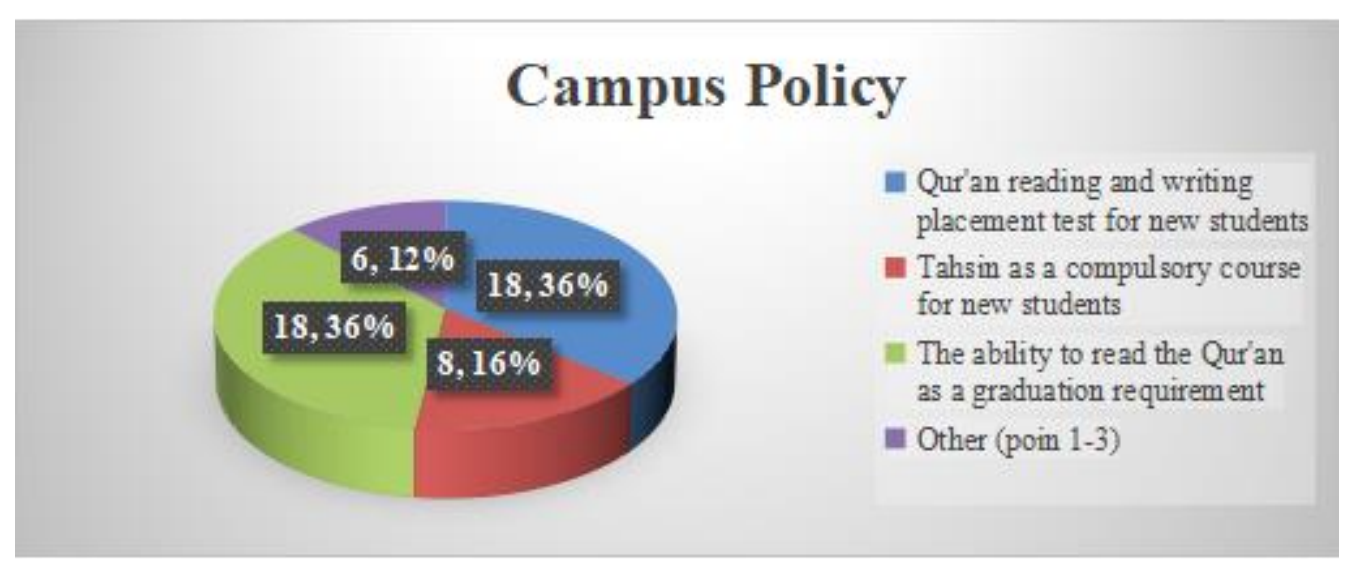

Fig. 1. Campus Policy.

Actually, the University already has a policy regarding the ability to read and write the Qur'an. There is a placement test related to the ability to read \& write The Qur'an for all new students. Then they are required to take tahsin classes in Mahad Jamiah for at least 3 months for those who has got the qualifications, and minimum 6 months for those who need to improve their ability. The important thing, the certificate of reading and writing the Qur'an is a requirement for student graduation.

However, this program is not well appreciated by all students. Some students from general study program have just joined the tahsin program before graduation. As a result, they have not been able to got the qualifications when they graduate. Dealing with the urgency of reading Al-Qur'an, most of the students realized that reading Al-Qur'an should be done on a 
daily basis, not occasionally. Campus need to enforce discipline on students to be motivated to learn Al-Qur'an. One of them is by monitoring the tahsin program, so that it can run well.

According to the various descriptions of the statistics above, UIN Ar-Raniry Aceh students' ability to write the Qur'an is often weaker than their ability to read the Qur'an. Students at UIN Ar-Raniry Aceh have a level 1 (poor) capacity to write the Quran (40\%), and a level 4 (high) ability to read the Quran (38\%). Second, depending on gender, the statistics found that male students at UIN Ar-Raniry have a poorer capacity to read the Qur'an than female students. Similarly, UIN Ar-Raniry Aceh male students' ability to write the Quran is lower than that of female students' capacity to write the Quran. Third, as compared to the General Study Program, the ability to read and write the Qur'an at UIN Ar-Raniry's Religious Study Program is higher. The students' Qur'an reading and writing skills are often poor. This is suspected for several reasons, including: first, students' lack of interaction with the Qur'an in their daily lives; second, a lack of environmental support, particularly from family, in developing the habit of reading the Qur'an; and third, students' lack of consistency in finishing the Qur'an (not to completion).

The conclusions of this study support the findings of Sofyan and Hendra's study, which indicated that UIN Ar-Raniry has sought to assist students in studying the Quran through Ma'had Jamiah, particularly by applying Quranic learning techniques to increase students' skills. However, owing to internal reasons (lack of motivation to read the Qur'an), some students still have below-average skills (lower marks)[20].

External factors such as a lack of family support, according to the research, also play a role in inspiring students to always interact with the Qur'an in their everyday lives. The presence of Ma'had Jamiah has been expected in order for students to reside in dorms that provide a more conducive environment for learning the Qur'an. However, additional research into the underlying causes (physiological and psychological) that contribute to UIN Ar-Raniry Aceh students' lack of enthusiasm to learn the Qur'an is needed in order to gain a more complete picture and a more definite remedy.

\section{Conclusion}

According to the findings of a study on the capacity to read and write the Qur'an among UIN Ar-Raniry Aceh students, the cause of their low ability to read and write the Qur'an is related to both internal and external causes. Internal factors focus on students' lack of motivation (and interest) in learning the Qur'an, as well as their lack of istiqomah (commitment) in learning the Qur'an (not abandoning the reading of the Qur'an until it is completed), whereas external factors focus on the family's less conducive environment in familiarizing students with the Qur'an in daily life. With the presence of Ma'had Jamiah, this has been attempted in the hopes of creating a $b a^{\prime} a h$, or atmosphere, that promotes the Qur'an learning process. Internal variables (physiological and psychological) must be investigated further to provide a more complete picture of the causes of inadequate capacity to read and write the Qur'an among UIN Ar-Raniry Aceh students.

Acknowledgments. The authors would like to express their gratitude to the chairman of the LPMQ (Lajnah Pentashihan Mushaf Al-Qur'an) Research and Development Agency and Training of the Ministry of Religion of the Republic of Indonesia for funding this study through the LPMQ DIPA. The authors also like to thank the resource people, field assistants, 
and responders at UIN Ar-Raniry Aceh, as well as everyone who has helped and supported the research up to this point.

\section{References}

[1] Abdul Chaer, Al-Qur'andan Ilmu Tajwid, (Jakarta: Rineka Cipta, 2013), 12.

[2] Ahmad Musthofa Al Maraghi, Tafsir Al Maraghi, Juz 11, h. 236.

[3] Ahmad Shams Madyan, Peta Pembelajaran Al-Qur'an, (Yogyakarta: Pustaka Pelajar, 2008), h. 109.

[4] Arcanita, Rafia. "Program Ma'had Al-Jami'ah IAIN Curup: Solusi Mengatasi Rendahnya Kemampuan Mahasiswa Membaca Al- Qur'an." EDUKASI: Jurnal Penelitian Pendidikan Agama dan Keagamaan 19, no. 1 (2021): 12-24.

[5] Ervika Dewi Wahyuni. "The Students Interest Towards Reading Al-Qur'an." JARES 3, no. 2 (2018): 10-19.

[6] Fauzan, Ahmad Hasyim, Pola Pembinaan Baca Tulis Al-Qur'an (Btq) sebagai Upaya Peningkatkan Kemampuan Membaca Al-Quran, Ar-Risalah, Vol. XIII No. 1 April 2015, 26.

[7] Giftia, Gina AD, Peningkatan Kemampuan Baca Tulis Huruf Al-Qur'an Melalui Metode Tamam Pada Mahasiswa Fakultas Sains Dan Teknologi Uin Sunan Gunung Djati Bandung, ISTEK Journal Edisi Juli 2014 Volume VIII No. 1, 143-158.

[8] Hakim, Rosniati. "The Improvement of Students ' Competence in Islamic Education Programme through Tahsin Al-Quran Activities.” Khalifa Journal of Islamic Education 3, no. 1 (2019): 35-52.

[9] Iffatunnuha, Kemampuan Baca Tulis al-Qur'an (BTQ) Mahasiswa Angkatan 2015 Prodi PAI Fakultas Tarbiyah dan Keguruan UIN Sunan Ampel Surabaya, 2019, 1-134.

[10] Jaeni, A., Akbar, A., Zarkasi, Z., Syatri, J., Mustopa, M., Musadad, M., Madzkur, Z., Irwan, I., Fadlly, H., Martiningsih, D., \& Purnawan, I. (2019). Indeks Kemampuan Baca Tulis Al-Qur'an Mahasiswa UIN di Indonesia: Tingkat Kemampuan, Faktor Penyebab dan Upaya Peningkatan. SUHUF, 12(2),303-326. https://doi.org/10.22548/shf.v12i2.486

[11] Komari, Metode Pengajaran Baca Tulis Al-Qur'an, Pelatihan Nasional Guru dan Pengelola TKTPA, (Makassar: LP3Q DPP Wahdah Islamiyah, 2426- Oktober 2008), h.4.

[12] Muhibbin Syah, Psikologi Pendidikan, (Jakarta:Raja Grafindo Persada, 2006), 148.

[13] Saiful Bahri Djamarah, Psikologi Belajar, (Jakarta: Rineka Cipta, 2011), h. 189.

[14] Siddiq, Hasbi, Kemampuan Baca Tulis Al-Qur'an dan Motivasi Tadarus Al-Qur'an. AlRiwayah: Jurnal Kependidikan, Volume 8, Nomor 2, September 2016, 337-354.

[15] Slameto, 2010, Belajar Dan Faktor-Faktor Yang Mempengaruhinya, Jakarta: Rineka Cipta.

[16] Supriyadi, Tedi, Universitas Pendidikan Indonesia, and J Julia. "The Problem of Students in Reading the Quran : A Reflective-Critical Treatment through Action Research." International Journal of Instruction 12, no. 1 (2019): 311-26.

[17] Nurchalis Sofyan, Hendra S. Strategi Pembelajaran al-Quran di Ma'had al-Jami'ah UIN arRaniry Banda Aceh, EDUKASI: Jurnal Penelitian Pendidikan Agama dan Keagamaan 17 (1), 2019, 70-80, p-ISSN: 1693-6418, e-ISSN: 2580-247X.

[18] T. M. Hasbi Ash Shiddieqy, Sejarah Dan Pengantar Ilmu Al-Qur'an dan Tafsir, (Jakarta:Bulan Bintang, 1980), h. 15.

[19] Tedi Supriyadi, Universitas Pendidikan Indonesia, and J Julia, "The Problem of Students in Reading the Quran : A Reflective-Critical Treatment through Action Research," International Journal of Instruction 12, no. 1 (2019): 311-26.

[20] Wawancara dengan Nurcholis (Pimpinan Ma'had al-Jami'ah UIN ar-Raniri Banda Aceh) tanggal 11 September 2019. 